szy na zagadnieniach dotyczących zagrożeń życia, wyzwalaja poczucie, że towarzyszy się jednemu dziecku we wszystkim, co go dotyczy. Oczywiście istnieje ,rysa na szkle", jest nią, przynajmniej z mojego punktu widzenia, nadmiar szczegółów; tysiące imion, nazwisk i przykładów przytaczanych często odnośnie tego samego zagadnienia sprawia, że miejscami czytelnik ma prawo czuć się znużony, chociaż może jest to odpowiedni czas, aby podnieść wzrok znad ksiażki i spojrzeć na własne dziecko, bawiące się na dywanie?

Dzieciństwo ma w sobie coś magicznego po części dlatego, że dla samego dziecka pozostaje ono po trosze tajemnica. $\mathrm{Z}$ tamtego okresu pozostaje na ogół mgliste wspomnienie, dotyczące zazwyczaj klimatu czy może lepiej aury, która wypełniała tamten czas. Oczywiste jest, że warunki czy otoczenie ulegaja zmianie, sa one bowiem uzależnione od postępu cywilizacyjnego, oczywistym jest jednak również fakt o istnieniu pewnej ciaglości. I ta ciagłość właśnie jest tak dla mnie zdumiewajaca, dotyczy ona pewnych pod- staw, które paradoksalnie i wbrew wszystkiemu pozostaja niezmienne. Miłość matki, jej oczekiwanje i nadzieja, jej dbałość o bezpieczeństwo, jej intuicja, wreszcie kołyska, grzechotka, zabawa w ciuciubabkę czy kołysanka śpiewana, by odpędzić złe duchy. „Każde dziecko jest fenomenem" - to słowa Jana Pawła II. Jak wiele innych nie są one żadną nowościa a jedynie przypomnieniem prawdy znanej już od dawna.

Nadia Kostrzewa

1 H. Bergson, Pamięć $i$ zycie, przekt. A. Szczepańska, Instytut Wydawniczy Pax, Warszawa 1996.

2 S. Łempicki, Dziecko w literaturze staropolskiej, "Kurier Literacko-Nukowy" 1938, nr 2.

$3 \mathrm{Ph}$. Ariês, Historia dzieciństwa. Dziecko i rodzina w dawnych czasach, tłumacz. M. Ochab, Gdańsk 1995.

4 Cyt. za: D. Żoładź-Strzelczyk, Dziecko w dawnej Polsce, Wydawnictwo Poznańskie, Poznań 2002.

5 Ph. Ariès, op. cit.

6 Jan Pawel II, Encykliki Ojca Świętego, Wydawnictwo Znak, Kraków 1996, s. 80.

7 Jan Paweł II, Evangelium Vilae, Encykliki Ojca Świętego, Wydawnictwo Znak, Kraków 1996.

\title{
Dorota Żołądź-Strzelczyk, Wiesław Jamrożek, Studia z dziejów edukacji kobiet na ziemiach polskich, Agencja Wydawni- czo-Poligraficzna „Bajt”, Poznań 2001, ss. 152
}

Wśród tematów poruszanych często przez badaczy kobieta zajmuje ważne miejsce. Jest bowiem zagadnieniem uniwersalnym $\mathbf{i}$ ponadczasowym zarówno w życiu i nauce, jak również w literaturze czy sztuce. „Świat bez kobiet byłby jak ogród bez kwiatów" - powiedział Pierre de Brantôme i trochę się wygłupił, bo świat bez kobiet nie mógłby w ogóle istnieć.

Na przestrzeni wieków kobiety były kojarzone bardzo różnie. Femme fatale, to kobieta fatalna, przynosząca zgubę mężczyźnie, z którym los ja zetknal. Kobieta bohater - to typ rycerski, kobieta, która przejmuje funkcje męskie, przywdziewa zbroję, idzie walczyć. Często kojarzono kobietę z aniołem, który oczarowuje i rozkochuje w sobie romantycznego kochanka. Była też kobieta kopciuszek, która robi błyskotliwą karierę tylko dlatego, że jest ładna i dobra.
Dziejom kobiet często poświęcano wiele uwagi. Amazonki - wojowniczki z mitologii, stworzyły własna, kobiecą krainę i obchodziły się bez mężczyzn. Literatura przedmiotu pokazuje, że one pierwsze parały się wojennym rzemiosłem, nie godzily się $z$ męskimi rzadami.

$\mathrm{Na}$ przełomie IV i $\mathrm{V}$ w. natomiast, jeden z podstawowych przedstawicieli starożytnej myśli chrześcijańskiej, św. Augustyn, nastawiony był wrogo wobec kobiecego rodu, widział w nim narzędzie szatana i źródło grzechów. Twierdził, że kobieta to zdeformowany mężczyzna. Z kolei reprezentant późnośredniowiecznej myśli chrześcijańskiej, św. Tomasz z Akwinu, także uznawal wyższość mężczyzny nad kobieta, ale tylko w sensie cielesnym, przyrodniczym, bo to właśnie mężczyzna zyskiwał chwałe $\mathrm{z}$ racji poczęcia potomstwa. Ale za to jako dusze - św. Tomasz 
uważał, że dusza męża i niewiasty sa równe i maja takie samo prawo przed Bogiem.

W średniowieczu występował także swoisty kult kobiety, który nakazywał rycerzom czcić „,cudną twarz", usługiwać damom i prowadzić z nimi konwersację.

W okresie romantyzmu kobieta przybiera dwa oblicza. Po pierwsze, jest to istota niewinna, podziwiana i ubóstwiana. Jest nieosiagalna, dziwnie niematerialna, dlatego kojarzy się $\mathrm{z}$ aniołem, a nie $\mathrm{z}$ dziewczyna. Gwałtowne namiętności budzila niewiasta wykształcona, inteligentna, a zarazem uczuciowa. $Z$ drugiej strony ta sama nieziemska istota jest też bezwolna ofiara: wydaja ją za mąz dla pieniędzy i pozycji społecznej małżonka, a ona nie broni ani swej miłości, ani marzeń. Sa jednak kobiety silne i niezależne, będące zaprzeczeniem melancholijnej, omdlewającej muzy romantyzmu. Najbardziej wyzwolona kobieta XIX wieku uprawiała sporty, grywała w karty, na co dzień chodziła w spodniach i cylindrze, a po domu w meskim szlafroku. Demonstracyjnie paliła cygara i nie kryła swych feministycznych poglądów.

$\mathrm{Z}$ upływem czasu obserwujemy zatem powolny wzrost pozycji kobiety. Wychodzac z cienia i zależności, powoli i systematycznie - szczególnie w wyższych sferach - emancypuje się i odrzuca krępujące ją ograniczenia.

W bieżacym roku nakładem Agencji Wydawniczo-Poligraficznej „Bajt” ukazała się książka pt.: „Studia z dziejów edukacji kobiet na ziemiach polskich". Jej Autorzy Dorota Żołąź-Strzelczyk i Wieslaw Jamrożek sa pracownikami naukowymi Wydziału Studiów Edukacyjnych Uniwersytetu Adama Mickiewicza w Poznaniu. W swoim dziele podjęli próbę ukazania dziejów edukacji dziewcząt i udziału kobiet w wychowaniu młodych niewiast na ziemiach polskich. Zamierzenie to jest niezwykle interesujące i ważne, albowiem dotyczy problematyki, która do tej pory nie doczekała się całościowego opracowania. Jak podkreślaja to również sami Autorzy wśród różnych aspektów życia kobiet częściej można było spotkać liczne biografie czy też opracowania dotyczace sytuacji prawnej znanych niewiast. Jednak problematyka oświatowa w odniesieniu do kobiet była stosunkowo słabo opracowana i fragmentaryczna, szczególnie dotyczyło to okresu przedrozbiorowego.
Recenzowana praca jest zatem pod wieloma względami wyjątkowa. Przede wszystkim przynosi ogrom informacji $z$ badań nad dziejami wychowania i ksztalcenia dziewcząt na ziemiach polskich.

Należy podkreślić, że do zalet pracy należy zaliczyć bogata podstawę źródłowa opracowania oraz niezwykle szeroki zakres podjętych zagadnień. Liczaca 152 strony ma charakter popularno-naukowy i składa się z dwóch części, uporzadkowanych według kryterium chronologiczno-rzeczowego.

Pierwsza część autorstwa Doroty Żołądź-Strzelczyk dotyczy dziejów edukacji dziewcząt i udziału kobiet $\mathrm{w}$ wychowaniu młodego pokolenia na ziemiach polskich $w$ okresie przedrozbiorowym.

Pierwsza część składa się z sześciu rozdziałów. Rozdział pierwszy poświęcony jest roli i pozycji kobiety w spoleczeństwie. Autorka analizuje w nim udział kobiet na dwóch plaszczyznach: rodzinnej (rola córki, żony - matki, wdowy) i społecznej (działalność w dziedzinach: gospodarczej, kulturalnej, oświatowej, politycznej). Na pograniczu tych dwóch płaszczyzn Autorka przedstawia kobietę zakonnicę.

Rozdział drugi charakteryzuje poglądy na wychowanie kobiet w średniowieczu i w okresie odrodzenia oraz postulaty wychowania kobiet zawarte w polskiej literaturze pedagogicznej XVI i XVII wieku . Wśród postulatów polskiej myśli o wychowaniu Autorka wyróżnia podejście ,,konserwatywne" - ograniczajace się tylko do wychowania religijno-moralnego dziewcząt, do kształtowania kobiety jako istoty biernej i uległej i „postępowe" - dostrzegajace w kobiecie istotę równą mężczyźnie, postulujące wychowanie intelektualne na równi z mężczyznami.

Rozdzial trzeci z kolei przypomina czytelnikowi, że edukacja młodych dziewcząt w domu rodzinnym miała znaczący wpływ na ich osobowość oraz przygotowywala je do wypełniania przewidzianych dla nich funkcji życiowych. Część ta poświęcona jest również wychowaniu młodych panien pod kierunkiem guwernantek, podkreślając, że wiele rodzin oddawało na wychowanie i powierzało kształcenie swoich córek osobom przypadkowym i całkowicie się do tego nie nadającym, co zapewne w wielu przypadkach miało bardzo negatywne skutki. Rozdział ten 
porusza również problem instytucjonalnych możliwości edukacji dziewcząt i młodych kobiet, podkreśla, że największa popularnością w tym czasie cieszyły się szkoły zakładane przy klasztorach żeńskich, kształcące przyszłe mniszki i panienki świeckic, a pod koniec XVIII wieku prywatne pensje dla dziewcząt.

Sporo miejsca o wychowaniu dziewcząt w Polsce osiemnastowiecznej poświęca rozdział czwarty, który zawiera wypowiedzi ówczesnych przedstawicieli oświaty i propozycje ich zmian.

W rozdziale piatym Autorka charakteryzuje działalność oświatową kobiet z perspektywy pełnionych przez nie ról: kobiety - matki, kobiety - opiekunki, piastunki, wychowawczyni. Poza domem miejscem pewnej aktywności kobiet - jak podkreśla Autorka - były dwory królewskie czy arystokratyczne oraz klasztory, w których obok działalności opiekuńczej kobiety prowadziły działalność oświatowa. Poza działalnością związana z wychowaniem i nauczaniem, kobiety były również mecenasami oświaty.

Część pierwszą kończy rozdział szósty, poświęcony edukacji dziewcząt $z$ polskich rodzin książęcych i królewskich.

W uwagach końcowych Autorka podkreśla, że udział kobiet w życiu intelektualnym Rzeczypospolitej systematycznie wzrastał, jednak w omawianym okresie przedrozbiorowym kobiety wykształcone stanowiły niewielką część kobiecej populacji.

Druga część recenzowanej książki napisana została przez Wieslawa Jamrożka i zawiera szkice poświęcone edukacji kobiet polskich okresu niewoli narodowej. W pierwszej częsci Autor analizuje problemy awansu społeczno-kulturalnego i edukacyjnego w programach ruchu kobiecego na ziemiach polskich $w$ XIX i na poczatku XX wieku. Autor podkreśla, że w swoich początkach ruch kobiecy był ograniczony do niewielkich środowisk, był to okres jego „budzenia się" i łączył się przede wszystkim z aktywnościa i koncepcjami edukacyjnymi Klementyny z Tańskich Hoffmanowej. Wzmożone zainteresowanie modernizacją wychowania kobiet wzmogło się na początku XIX wieku, kiedy uwolniono się od cudzoziemszczyzny, zwłaszcza francuszczyzny. Zainteresowanie to zaczęły uzewnętrzniać bardziej światłe kobiety - literatki, szczególnie Izabela Czartoryska, Maria Anna Wirtemberska, An- na z Krajeńskich Nakwaska czy wspomniana już Klementyna Tańska Hoffmanowa.

Ideę emancypacji kobiet zaczęto głosić w okresie pojawienia się tzw. entuzjastek, przedstawicielek kobiet pochodzenia ziemiańskiego. $\mathrm{Z}$ jednej strony dążyły one do uzyskania stosownego wykształcenia i niezależności materialnej, a $\mathrm{z}$ drugiej strony do równoprawnego z mężczyznami udziału w życiu społeczno-politycznym. Należy podkreślić, że najwybitniejsza przedstawicielka tego grona była Narcyza Żmichowska.

W zakończeniu pierwszej części Autor podkreśla, że wiek XIX i poczatki wieku XX charakteryzuje fakt, iż o zmianie statusu społecznego kobiet i o modernizacji ich edukacji zaczynaja mówić przede wszystkim kobiety. Ruch kobiecy krystalizowal się jednak w specyficznych warunkach niewoli narodowej, a kwestie narodowe stawały się ważniejsze od idei równouprawnienia.

Druga część omawia udział kobiet w polskim ruchu oświatowym Galicji na przełomic XIX i XX wieku. Autor podkreśla, że ruch kobiecy na ziemiach polskich $w$ omawianym okresie różnił się od ruchu feministycznego w Europie Zachodniej przede wszystkim tym,że kwestia kobieca podejmowana była przez feministki w warunkach niewoli narodowej. Polki z jednej strony współzawodniczyły z mężczyznami o równouprawnienie, a $z$ drugiej brały udział $w$ walkach o wyzwolenie swojego kraju z niewoli politycznej, w przemianach społecznych i ekonomicznych.

Podejmowanym przez ruch feministyczny w Galicji wysiłkom wychowawczym i oświatowym przyświecał wzór kobiety - obywatelki. Zmierzano zatem do poszerzania zakresu uczestnictwa kobiet w stowarzyszeniach ksztalcacych, zawodowych, kobiecych. Dużą aktywność przejawiały kobiety $w$ pracach największego towarzystwa oświatowego Galicji, Towarzystwa Szkoły Ludowej; uczestniczyły w zajęciach oświatowych oferowanych przez własne stowarzyszenia.

Rola kobiet w ruchu oświatowym Galicji polegala zatem na inicjowaniu i organizowaniu różnych przedsięwzięć edukacyjnych oraz na udziale $w$ innych formach edukacji w charakterze słuchaczek, czytelniczek czy uczestniczek kursów. Ruch ten przyczynial się do ich społeczno-kulturalnej emancypacji. 
Prezentowana książka przekazuje wiedzę o edukacji kobiet na ziemiach polskich w wyjatkowo przystępnej formie. Czytelnik otrzymał pracę napisana żywym i barwnym językiem.

Dokonując oceny merytorycznej pracy autorstwa Doroty Żołądź-Strzelczyk i Wiesława Jamrożka $\mathrm{z}$ cala powaga można stwierdzić, że wypełnia ona w sposób niezwykle istotny dotychczaso- wą lukę w badaniach nad problematyką edukacji kobiet $w$ okresie przedrozbiorowym i w wieku XIX i XX. Cieszy fakt, iż zagadnienie to znalazło się w centrum zainteresowań badawczych ośrodka poznańskiego.

Reasumując, książkę z pewnością można polecić jako godna uwagi lekturę dla każdego, kto interesuje się problematyka kobieca.

Matgorzata Postuszna

\section{Noty}

\section{Małgorzata Balukiewicz, Protektoraty lwowskie. Poczatki i roz- wój praktyki opiekuńczo-wychowawczej we Lwowie i na ziemi lwowskiej od końca XVIII stulecia do wybuchu II wojny świato- wej, Katowice 2000, ss. 158}

Wydawnictwo Uniwersytetu Śląskiego w 2000 roku zrobiło miłośnikom Kresów Wschodnich niewątpliwa przyjemność publikując pracę Małgorzaty Balukiewicz pt.: Protektoraty lwowskie. Poczatki i rozwój praktyki opiekuńczo-wychowawczej we Lwowie $i$ na ziemi lwowskiej od końca XVIII stulecia do wybuchu II wojny światowej. Przyjemność ta jest dwojakiego rodzaju. Po pierwsze, dotychczas brak było pełnego opracowania na temat historii pedagogiki opiekuńczej w odniesieniu do Kresów, a po wtóre autorka uczynila to $z$ wyjątkowa dokładnościa i znajomością tematyki. Świadczyć o tym może chociażby bogactwo materiałów źródłowych, potwierdzajacych dorobek społeczności ziemi lwowskiej w zakresie niesienia pomocy, a z których to autorka pracy skorzystala w swoich badaniach. Poza materiałami archiwalnymi i źródłami drukowanymi M. Balukiewicz wykorzystała wspomnienia lwowian i osób, które zamieszkiwaly dawną stolicę Galicji, a które po II wojnie światowej zostały zmuszone do opuszczenia rodzinnego miasta. Ba$\mathrm{ze}$ materialowa uzupełniły ponadto dzieła naukowe $z$ zakresu pedagogiki $i$ dziedzin pokrewnych oraz czasopisma poświęcone problematyce spoteczno-pedagogicznej, lokalna prasa codzienna, a takze opracowania biograficzne, dotyczace osób działajacych na badanym terenie.

Praca składa się $\mathrm{z}$ trzech rozdziałów. Pierwszy z nich opisuje tradycje opiekuńczo-wychowawcze ziemi lwowskiej do roku 1918. Autorka przybliżyla w tej części pierwsze inicjatywy opiekuńcze w okresie przedrozbiorowym, w zaborze austriackim, dzialania opiekuńczo-wychowawcze w latach autonomii galicyjskiej i I -wszej wojny światowej, reformę systemu opieki samorządowej we Lwowie, rozwój opieki zakładowej, a także działalność różnorodnych stowarzyszeń, fundacji i organizacji społecznych. W rozdziale drugim $\mathbf{M}$. Balukiewicz przedstawiła kierunki i formy działaIności opiekuńczo-wychowawczej we Lwowie i w województwie lwowskim w czasach Drugiej Rzeczypospolitej. Szczególnym zainteresowaniem autorki cieszyły się inicjatywy opiekuńczo-wychowawcze w okresie formowania się granic państwa i na tle ustawodawstwa polskiego. Ponadto przedstawione zostały: rozwój teorii pedagogiki społecznej w Drugiej Rzeczypospolitej 